\title{
Glimpses of Indian Historical Demography
}

\author{
by Parameswara Krishnan \\ Delhi: B.R. Publishing Corporation 2010 \\ ISBN 978-8176466387 \\ Hardcover, \$17.76 (995 INR), 232 pp.
}

\author{
Reviewed by Anatole Romaniuk, Adjunct Professor \\ Department of Sociology, University of Alberta (Edmonton, Canada) \\ anromaniuk@yahoo.ca
}

Going deep into the past, well into the preliterate era, the "historical demography of India is no doubt a complicated jigsaw, with several pieces missing," writes Professor Krishnan Namboodiri, who prefaced the book. And indeed, with few exceptions - the closest one to us Canadians being French Canada, with its parish registers from the earliest days of French settlement-historical demographers have always had to contend with data problems. The first decennial census in India was taken in 1881, under British rule. The author, as others researchers, had to resort to stable and quasi-stable population models to derive estimates of basic demographic parameters, such as age distribution, fertility, and mortality, from the successive censuses. This has been supplemented by mini-surveys and local Christian church registers. As for more remote times, Krishnan had to rely on ancient literary records that are only indirectly connected to demography, and as such, he notes, they are no substitute for "systematic accumulated certified knowledge."

Yet this medium-sized book is rich in content, so much so that selection and focus had to be exercised in order to limit the remarks below to a few features.

First, what came to this reviewer's attention is India's population growth-its historically protracted stagnation, followed by impressive growth which continues today. With its 1.3 billion inhabitants, India ranks a close second only to China (1.4 billion). However, its population, unlike that of China, is expected to grow further, and may reach 1.7 billion by mid-century. Yet what is today a hugely populated country was, if not a demographic emptiness, then definitely only a sparsely inhabited one. According to the estimates quoted by Krishnan, its population was only 100 million by 1600 and remained nearly stationary until well into the second half of the 19th century, when it reached 255 million according to the 1881 census. Krishnan quotes the population in the range of 100-140 million for ancient India around 300 BC. Though we shall treat these ancient figures with a great deal of scepticism, they nevertheless denote the stagnant state of demography in India well over millennia, as it was in most of the world in those times. Recurrent famines and epidemics (smallpox, influenza, cholera, fevers), and other natural calamities due to geography and climate, may have indeed kept the population low on the Indian subcontinent. However, we know little about specific events that may have also undermined its growth, similarly as in other parts of the world. The demographic collapse in the Americas, we know, was triggered by the introduction of new infections for which Indigenous populations lacked natural immunity, and which caused long-lasting havoc to their demography. In Africa, the culprit of human devastation were sleeping diseases, spread by the tsetse fly. The three centuries of shipping slaves from Africa to America were also a factor. Venereal disease-induced massive sterility was a potent factor in the depopulation of central Africa. None of these seems to have taken place in India. Certainly India had its share of man-made calamities (wars and revolutions) that historically kept population growth at bay. The absence of states capable of organizing and ensuring internal peace and security from outside predators can be blamed for underpopulation in India — as in 
pre-Columbian America or pre-colonial Africa and many other parts of the world. Pax Britannica brought some relief in this regard to the Indian subcontinent.

What makes Krishnan's book of particular interest to demographers, in this reviewer's opinion, is the discussion of Indian fertility, its ethno-religious differentials and their determinants. At very first glance, the reader is inescapably impressed by the overall low birth and fertility of India's populations, uncharacteristically low for a pre-modern demography. The reported rates hardly exceed 40 births per 1,000 population and five births per female generally. This is particularly true of the Hindu, by far the largest group, historically in the range 72 to 82 per cent of India's total population. The Hindu birth rates are in the rage of 31 to 37 per 1,000 population and a total fertility of 4.7 to 5.2 children per female, according to the Bogue/Palmer estimates derived from the proportion of children under age 15, as per 1881 and 1891 censuses. “...Hindu fertility was muzzled within a span of 90 years-nearly five children per female” writes Krishnan (p. 32). The second-largest group of India, Muslims - a population comprising about 20 per cent of the total Indian population prior to the partition, and 10 per cent presently_does somewhat better in this regard, being credited by a birth rate in the range of 36 to 40 and total fertility of between 5 and 6 children per female, according to the 1891 census. Weighing all available estimates, Krishnan concludes that "the total fertility rate of the Muslims was five to six children per woman over the past hundred years" (p. 46). To be sure, we need to take statistics of that time with due caution. How can we explain that the ratio of children $0-4$ and of 5-9 to women in the reproductive ages for Bengali Christian villages yields a crude birth rate estimate of 27.6 and 49.6 per 1,000, respectively (the method of estimate, that by Bogue/Palmer, being identical in both cases; see p. 69)? Should we suspect here the effect of gross age misreporting? It might indeed be the case, as the two age groups combined (0-14) yield a more likely rate of 35.5 per 1,000 .

Notwithstanding these and similar statistical oddities, and the actual ethno/religious variations, it remains that birth and fertility rates reported for Indian populations are on the low side, as for a pre-transition population not practicing contraception and following universal marriage. We find many African populations, even today, with crude birth rates in the range of 50 to 60 , and total fertility of 7 to 8 births per female. Even the somewhat higher Indian Muslim fertility compares poorly with contemporary Muslim populations in Africa, such as Mali and Niger, with a birth rate over 50 per 1,000. It is true that the Indian birth rate comes closer to that of 18th-century Western Europe-about 40 per 1,000. From the work of John Hajnal on the historical Western European family, however, we know that the relatively low traditional birth rate in Western Europe was due to late and low marriage practices - the consequence of inheritance customs to keep the family holdings intact. In many cases, only the oldest son was entitled to inherit the parental estate, while the younger children were left out, often condemned to permanent celibacy. In Eastern Europe inheritance customs were more egalitarian, and birth rates were substantially higher. In Ukraine, for example, all children were entitled to a portion of the parental holdings, and the youngest son usually retained the parental home. As a consequence, marriage was universal and relatively early (on average at age 18 for girls and age 20 for boys), and birth rates were high, in the range of 50 per 1,000 population. In India, or more precisely in Kerala, among the Christians the inheritance rule, according to Krishnan, "followed the patriarchal system and the inheritance pattern was to divide the property among all sons, with the youngest son usually bequeathed the parental home..." (p. 81).

So what are the reasons for the rather low childbearing performance in India, practically across all the ethno-religious divides? In India marriage was universal, and early, perhaps far too early. Girls were betrothed in pre-puberty, and possibly sexually consummated. Can this be a factor, given that pre-puberty or even early puberty sexual exposure can impair a woman's procreative ability (i.e., sub-fecundity, secondary sterility, etc.) at later ages? An exploration into these matters would shed light on these questions. The reader would have welcomed a more elaborate discussion along these lines than the book currently offers. On the other hand, the book makes a strong case for the custom of prohibiting remarriage of widows as the single most important factor of relatively poor childbearing performance among Indian women, more specifically among Hindus. In a regime of very high mortality, the widows represent a significant proportion in the pool of females of reproductive age, and hence widowhood stands out as a potentially important procreation-depressing factor. Such custom does not apply to Muslims or Christians. Also, Muslim and Christian girls marry at a somewhat later age, and their fertility is indeed somewhat higher, but not high enough, we have seen. So the question of the overall 
low traditional birth rate among Indians remains somewhat foggy. Nevertheless, with all the downward biases we may suspect in the statistics on India's fertility, Krishnan's and other studies suggest that its levels are much below the biological maximum possible, lower than those recorded in pre-industrial European populations, particularly of Central and Eastern Europe, let alone of many earlier developing countries. And this seems to be rooted in biology, as well as in the prevailing cultural and institutional checks on fertility operating both within and outside marriage — such as the already mentioned non-remarriage of widows, as well as post-childbearing sexual abstinence and extended separation of spouses due to mothers returning to their kin with the newborn.

The book carries the investigation into a comparative demography of childbearing, by bringing into the picture other typical religious groups. The Christian minority (11 million, 2 to 2.6 per cent) is a case in point, in that it brings to bear on matrimonial and procreative behaviours, what I would call civilizational imports from the Western world through the conversion to the Christian faith. The inter-civilization contacts go back to the 15 th century with the coming of the Portuguese, Dutch, French, and British, followed by missionaries to the southern (Kerala) and western shores of India (Goa). As a result, certain fertility-inhibiting factors, such as those already mentioned, may have been removed or weakened. As indicated, Christians do marry somewhat later and their fertility is higher, closer to that of Muslims. But the very "modernizing" forces that initially helped fertility upward have in recent years triggered a decline in fertility, so much so that another distinguished demographer of Indian background, M.V. George, qualified the Kerala State (the most Christianized and most advanced in India by such criteria as literacy, urbanization, and upward mobility) as a "unique example of below-replacement fertility in a high-fertility country."

The Sikh community, most prevalent in the Punjab state, offers yet another illustration of the workings of what may be called the "protestant ethic" and prudential attitudes in shaping procreative behaviours. "Sikh religion did away with many of the antiquated social practices that have a depressing effect on fertility (various sexual taboos, prohibition of widows' remarriage), but also espoused social norms that triggered fertility control through contraceptives, sterilisation..." "Sikhs are open to "novel ideas/innovation." "The Sikh female is the most emancipated in the sub-continent" (p. 111). It is among the Sikhs that the slogan "economic development is the best contraception" is best exemplified in India.

A similar ideational setting is found in the Jaina community, which is a low-fertility, small business-oriented minority group comprising only 0.50 per cent of the total population. "Achievement in one direction (business) calls for sacrifice in other areas, as one's own fertility" (p. 136)—or, in demographic parlance, work and parenthood incompatibility, or opportunity costs. These propensities are even stronger among such "achievement minorities" as the small Indian Jewish and Zoroastrian Parsis communities. Their traditional fertility is indeed so low that they may be on the verge of disappearing in India. In trying to maintain their identity, at the expense of their demographic vitality they practice marital homogamy, which has resulted in a fair degree of inbreeding: "Due to the paucity of sexual partners in small genetic pool, the Parsis have used inbreeding for conjugal relationships..." (p. 183), hence the group is liable to excessive incidence of genetic disorders.

In his analysis of procreative behaviours of the Indian sub-populations, Krishnan refers in various places to the concept of upward mobility. That is, parents limit their fertility in order to provide their children better opportunities for socioeconomic advancement. This tendency is highly prevalent among Christians, Sikhs, and Jains, but in short supply among the Hindu majority and particularly among Muslims (the French sociologist Arsene Dumont attributed to this tendency among parents the secular decline of fertility in France).

To a reader, as this reviewer, who has heard so much about Indian society's all-pervasive caste system, there is surprisingly no discussion of its demographic ramifications. The author makes only a brief reference to tribal communities (known also as Aboriginals), living in isolation deep in the jungles and mountains, but hardly any to the caste hierarchy proper that cuts across ethno/religious sub-populations in India. What are the matrimonial and procreative behaviours of the lower castes-Untouchables, for example-compared to the upper castes, like Brahmans, who enjoy higher standards of living as well as greater social and political privileges? How, in comparison do the poverty-stricken lower castes fare reproductively?

To this reviewer, who cannot claim any in-depth knowledge of India and its demography, the reading of the book was highly educational as well from the perspective of what can be called political demography. India throughout history has had its share of upheavals, wars, occupations, and civil unrests, which have brought suffering 
and devastation. The latest of these were the massive displacement of populations, the partitioning of the country following independence from British rule, and even today, ethnic, religious, and social conflicts are not uncommon. But on the whole, since independence India has worked out viable accommodations that allow this multi-ethnic, multi-linguistic, and multi-religious country to maintain internal peace and to uphold democratic values. If there is any country destined to carry forward values of western liberal democracy into the emerging post-western world, it is India - a demographic giant on the verge of becoming an economic giant and a world power. No one can doubt anymore the global geopolitical importance of this great, populous nation.

Professor Krishnan (who is also, if I may remind our readers, the founder of this journal) has made a valuable contribution to the historical demography of India. As mentioned from the outset of this review, there are still gaps that remain to be filled and some demographic features identified in need of elaboration. Nonetheless, it is a pioneering venture that sets the stage for further in-depth work on Indian historical demography. With its great mixture of ethnic, religious, and social systems, India can be seen as a vast laboratory for comparative demographic research.

\section{References}

Davis, K. 1951. The Population of India and Pakistan. Princeton, MA: Princeton University Press.

Hajnal, J. 1982. Two kinds of preindustrial household formation. Population and Development Review 8(3):448-494.

George, M.V. 2010. The fertility decline in India's Kerala state: A unique example of below replacement fertility in a high fertility country. Canadian Studies in Population 37(3-4):563-629. 